\title{
A guerra imaginada entre secularismo e religião'
}

Mark Juergensmeyer ${ }^{2}$

\section{Resumo}

O caso do ataque aos escritórios da revista satírica Charlie Hebdo, em 2015, em Paris, ilustra a guerra imaginada entre secularismo e religião que serve de pano de fundo a muitos dos episódios de violência na virada do século XXI. A ideia do lluminismo de que existem duas cosmovisões diferentes - duas esferas distintas de compreensão da realidade -, uma secular e outra religiosa, é inerentemente problemática. Essa dicotomia cria uma arena de discórdia que é facilmente explorada por pessoas que, por qualquer motivo, se sentem isoladas e marginalizadas, procurando culpar alguém e juntar-se a alguma batalha. É um falso conflito que os extremistas de ambos os lados, religiosos e seculares, têm exacerbado.

Palavras-chave: Terrorismo. Violência religiosa. Secularismo. Guerra cósmica.

\section{Introdução}

"O secularismo é o inimigo do Islâ", foi-me dito por um militante muçulmano que esteve envolvido no ataque ao World Trade Center em Nova Iorque, em 1993. Ele associava as políticas econômicas e governamentais adversas do Ocidente à "inexistência de moral", descrevendo aqueles sem religiáo como pessoas "apenas andando como cadáveres".

Esse desdém pelo secularismo - e o medo dele - é um refráo comum; e eu o escutei em várias entrevistas com ativistas religiosos por todo o mundo4. Independentemente de eles serem jihadistas muçulmanos militantes, ativistas

\footnotetext{
1 Tradução de Jorge Botelho Moniz.

2 Professor associado na Universidade da Califórnia, Santa Bárbara (EUA), fundador e diretor do Orfalea Center for Global and International Studies, diretor do grupo Religion and International Affairs para o Social Science Research Council que resultou no volume Rethinking Secularism.

3 Entrevista do autor com Mahmud Abouhalima, Penitenciária Federal de Lompoc, Califórnia, 19 de agosto de 1997.

4 Muitas dessas entrevistas encontram-se em meus livros: Terror in the Mind of God: The Global Rise of Religious Violence (Berkeley: University of California Press, 2003) e Global Rebellion: Religious Challenges to the Secular State (Berkeley: University of California Press, 2008).
} 
judeus antiarabistas, ou membros da milícia cristã em Maryland, esses ativistas consideram que o mundo é vulnerável a uma mentalidade secular dominante que pretende obliterar suas frágeis culturas religiosas. Um pastor luterano que esteve envolvido nos ataques à bomba em clínicas da costa Leste dos EUA (Estados Unidos da América), onde eram realizados abortos, disse-me que açóes como as suas eram apenas um prelúdio da guerra contra o secularismo. Em sua cabeça a cultura de guerra entre a sociedade secular e religiosa estadunidense era mais que uma metáfora. Era uma batalha real.

Essa é a percepção. Os receios podem ser amplamente embasados em exagerações, mas existem muitos exemplos na cultura popular nos quais as expressóes da religião são marginalizadas ou desrespeitadas, fazendo com que algumas pessoas religiosas sintam que sua cultura está sob ataque. Por exemplo, a tentativa francesa de banir os véus, ainda que baseada na noçáo de igualdade social, foi largamente interpretada, pela comunidade imigrante muçulmana argelina em França, como uma agressão à sua religião em geral e à sua cultura imigrante em particular. Os casos do retrato do profeta Maomé em forma de caricatura levaram a encontros trágicos e explosivos, tanto em Copenhague como em Paris.

\section{O caso do ataque ao Charlie Hebdo}

$\mathrm{O}$ ataque à sede da revista satírica francesa Charlie Hebdo, em Paris, em 7 de Janeiro de 2015, é um exemplo interessante. Por um lado, foi apenas um caso de jovens enfurecidos e perdidos que descarregaram sua raiva da sociedade em um alvo simbólico. Mas, por trás desses fatos simples, havia uma narrativa mais ampla acerca da alienação da comunidade muçulmana argelina na França e sua percepçáo de que o secularismo estava sendo interpretado de um modo que se destinava, especificamente, a despojá-los e humilhá-los. À medida que os jovens muçulmanos, perpetradores dessa agressão de estilo militar, se afastavam da cena do massacre, exclamaram que ela tinha sido uma vingança pelos insultos efetuados através das caricaturas do profeta Maomé.

Contudo, esse não foi um caso de terrorismo islâmico puro e simples, contrariamente ao que políticos e jornalistas apregoaram na época. $\mathrm{O}$ senador Lindsey Graham, por exemplo, disse que os ataques de Paris provam que o Ocidente se encontra em uma guerra religiosa com o radicalismo islâmico. 
O respeitado jornalista, George Packer, apressou-se em publicar um artigo de opinião no site do The New Yorker, afirmando que esse ato nada tinha a ver com as tensôes étnicas em França e que tinha sido apenas um ataque calculado em nome da ideologia islâmica. O Twitter e o Facebook encheram-se de acusaçôes de que, uma vez mais, a religiáo islâmica incitara os seus fiéis à violência.

A religião fazia, certamente, parte da equação. No entanto, a forma exata como ela entra na questão é mais complicada do que a simples asserção de que a ideologia islâmica atacou de novo. Sabíamos o suficiente sobre os envolvidos para saber como suas histórias de vida se cruzavam com a ideologia religiosa extremista. De certa forma, sua situação era similar a muitos outros ataques terroristas de lobo solitário praticados na Europa e nos EUA nos últimos anos. Antes de Paris, houve o ataque dos irmáos Tsarnaev, no massacre de Boston de 2013; a agressão letal a um acampamento juvenil norueguês pelo extremista cristão Anders Breivik, em 2011; o ataque ao templo sikh de Milwaukee por Wade Michael Page; e, antes disso, as tentativas de bombardeio a Times Square, por Faisal Shahzad, em 2010, e ao parque olímpico de Atlanta, por Eric Robert Rudolph, em 1996, relacionado ao movimento da Identidade Cristá. Esses eventos de lobo solitário são diferentes de outros casos em anos recentes onde, grupos radicais organizados, com a religião como parte de sua ideologia, tais como o ISIS (Estado Islâmico do Iraque e do Levante) ou a milícia cristá, planejaram ataques e recrutaram participantes para suas açóes. Nos casos de lobo solitário, as ideias religiosas, quando surgiram, serviram mais de desculpa do que razão para a violência. No caso do incidente de Paris, pelo menos um dos irmãos pode ter tido ligaçóes à al-Qaeda do Iêmen, mas não há provas de que tenham sido enviados por alguma autoridade superior da organização para cometer o crime. De fato, a religiáo parecia ser um aspecto menor de suas motivaçóes.

Os irmáos Said e Cherif Kouachi não eram santos. Foram criados em um lar secular e sua juventude foi cheia de pequenos delitos. Nunca tiveram emprego estável, apesar de Cherif ter entregado pizzas ocasionalmente. A atraçáo pela ideologia jihadista parecia ser primariamente um chamado de guerra, acoplado a um sentimento de honrar suas comunidades e eles próprios, uma desonra conquistada com seu estilo de vida errático. Segundo o New York Times, Cherif Kouachi gostava de fumar maconha e escutava música rap; ele 
se descreveu como um muçulmano ocasional. Nenhum dos irmãos parece ter tido uma noção muito sofisticada de sua fé nem da ideologia jihadista islâmica. Eles queriam simplesmente fazer parte de uma luta.

A batalha que escolheram foi, porém, a guerra ao secularismo. $\mathrm{O}$ alvo de seu ataque furioso e cruel foram os satiristas seculares que retrataram o profeta Maomé em caricaturas. Esse é o tipo de insulto à religião que ofenderia qualquer muçulmano, não apenas os enfurecidos como os irmãos Kouachi. Fazer pouco de políticos e figuras públicas é uma coisa, depreciar a cultura de alguém é bem diferente. As imagens na revista Charlie Hebdo são semelhantes às caricaturas étnicas de judeus na Alemanha nazista ou aos desenhos de japoneses dentuços e de óculos em cartazes estadunidenses da II Grande Guerra. Esses desenhos denigrem uma raça ou cultura inteira, no caso dos muçulmanos.

Os muçulmanos argelinos na França já se sentem diminuídos e, para muitos, as caricaturas foram "a última gota". Isso levanta um assunto que George Packer, em seu ensaio no New Yorker, disse que devíamos ignorar especificamente: as tensôes multiculturais da sociedade francesa contemporânea. Se alguém estiver procurando um elo que conecte o sentimento pessoal de raiva e alienação de um par de indivíduos a uma demonstração pública de como a comunidade imigrante, da qual fazem parte (muçulmanos argelinos), se sente enraivecida e alienada na França contemporânea, então o caso das caricaturas é a conexão perfeita. Além disso, existe uma ideologia islâmica radical dominante que apresenta uma imagem de guerra cósmica entre o islá e a sociedade secular, permitindo que essas demonstraçóes individuais de frustração e raiva sejam exaladas. É por isso que a identificação de Packer da ideologia jihadista como um fator é importante, porém as provas não indicam que seja a única causa do ataque; pelo contrário, é o veículo pelo qual uma aversão pessoal ou étnica é expressa.

Para uns irmãos Kouachi desonrados e encurralados, a ideia de fazer parte de uma grande batalha entre secularismo e religiáo pode ter parecido atrativa por várias razóes. Para tais pessoas as guerras reais são entusiasmantes e as batalhas imaginadas de grandes conflitos religiosos são mais do que estimulantes. Elas também oferecem a promessa de oportunidade, a possibilidade de desempenhar um papel enobrecedor dentro dessa guerra cósmica. Talvez de forma mais direta, tais guerras imaginadas oferecem a justificação para fazer algo 
destrutivo àquela sociedade que consideram tê-los ignorado, bem como às suas comunidades. Assim, a defesa da religiáo serve de pretexto para a violência. Oferece licença moral para algo horrível que os perpetradores possam ter desejado fazer, mostrando ao mundo quão poderosos eles e suas comunidades podem realmente ser e demonstrando sua importância em um momento derradeiro de glória violenta.

Em outros casos, a guerra imaginada entre secularismo e religiáo tem, igualmente, dado a homens enfurecidos (e são invariavelmente homens) a oportunidade de demonstrarem sua capacidade de proteção varonil, por meio de atos de violência contra símbolos de secularismo e tolerância multicultural. Nos casos do assassino do acampamento juvenil norueguês, Anders Breivik, do bombista do parque olímpico de Atlanta, Eric Robert Rudolph, e do agressor do templo sikh, Wade Michael Page, suas motivaçóes parecem ter incluído a defesa imaginária da sociedade cristá. $\mathrm{O}$ indivíduo que tentou bombardear Times Square, Faisal Shahzad, e os homens-bomba de Boston, Tamerlan e Dzhokhar Tsarnaev, justificaram seus atos de raiva como defesa da sociedade islâmica, tal como os agressores de Paris, Said e Charif Kouachui.

As motivaçôes que animaram estes ativistas não são, em sentido estrito, religiosas. Elas têm a ver com a alienação étnica e cultural e com os temores de integraçáo étnica em uma sociedade multicultural. Combinam a perda pessoal com o sentimento de humilhação sofrido em tempos de transformação social, e essas emoções humanas compreensíveis podem ser demonstradas de muitas maneiras. Todavia, aqui são expressas através de um ódio às instituiçôes seculares e de uma perspectiva imaginada do secularismo e religiáo reclusa em uma espécie de guerra cósmica. Qual a razão para isso?

Uma resposta a esta pergunta é que a religião é culpada. Ao exagerar os perigos da ciência e de uma ordem racional desprovida de religiáo, cria uma resposta extrema e um inimigo imaginário. Isso explica o fenômeno do fundamentalismo, um movimento que se desenvolveu no cristianismo protestante estadunidense, nas primeiras décadas do século XX e se tornou em um rótulo global para demarcar qualquer tipo de conservadorismo religioso antimodernista ${ }^{5}$. A outra resposta é que o secularismo é o problema. Ao criarem

5 Conforme, por exemplo, os liuros do The Fundamentalism Project, editado por Martin Marty e Scott Appelby e publicados pela University of Chicago Press durante as décadas de 1980-1990. 
sociedades estéreis a qualquer forma de cultura religiosa, negam às pessoas religiosas expressóes do que para elas é parte essencial de suas identidades. Daí a reação contra a proibição do véu em França e o apoio religioso a movimentos políticos na Turquia, inversores das políticas antimuçulmanas extremas de Kemal Ataturk e promotores da expressão pública de marcas de identidade religiosa.

As duas posições têm alguns méritos, mas as formas extremas tanto da religião como do secularismo são problemáticas. Neste artigo, porém, desejo me focar em um aspecto diferente da situação: a relação do secularismo e da religião entre si. A própria ideia de que existem duas cosmovisôes diferentes duas esferas distintas de entender a realidade - uma secular e outra religiosa, é inerentemente problemática. Essa dicotomia cria uma arena de discórdia que é, por qualquer razão, facilmente explorada por pessoas que se sentem isoladas e marginalizadas e que procuram alguém para culpar e alguma batalha para se juntar, a guerra entre secularismo e religiáo. Como surgiu essa dicotomia?

\section{A invenção do secularismo e da religião}

Apesar de suas origens serem relativamente bem conhecidas, náo é totalmente claro como esta bifurcação entre os mundos secular e religioso persistiu e por que reemergiu no mundo contemporâneo. Ela é frequentemente descrita como sendo uma invenção do Iluminismo europeu, embora houvesse precedentes, dependendo do que se entende por secular ou secularismo. A definição dos termos não é tão óbvia quanto se possa imaginar. Uma força-tarefa do Social Science Research Council em Nova Iorque convocou um projeto plurianual, presidido por mim, para repensar o secularismo e concluímos que esta é uma noção complexa, ou melhor, um conjunto de noçôes que é vista diferentemente em diferentes culturas (CALHOUN; JUERGENSMEYER; VAN ANTWERPEN, 2011) ${ }^{6}$. Em suas várias formas, o secularismo é em si mesmo algo - não apenas a ausência de religiáo. É uma cosmovisão carregada de pressupostos valorativos sobre a natureza do indivíduo e sua relação com a sociedade.

6 Partes desse artigo foram adaptadas a partir de seções do meu trabalho no Rethinking Secularism. Ver também: Asad, 2003. 
De acordo com o filósofo canadense Charles Taylor (2007), em seu livro magistral sobre a ascensão do secularismo no Ocidente, existem três formas de pensar o secularismo. Uma é a separação Estado-Igreja - mantendo a separaçáo entre autoridades religiosas e políticas. Desde os tempos bíblicos que essa tem sido uma característica da maioria das tradiçóes religiosas - expressa no ditado atribuído a Jesus, respondendo se os crentes deviam pagar o imposto romano: "Dai a César o que é de César, e a Deus o que é de Deus (Mateus 22:21). O segundo tipo de secularismo é a remoçáo de elementos religiosos da vida pública e a criação de uma espécie de cultura pública que os substituam. Enfim, o terceiro tipo de secularismo é a emergência da pessoa secular - aquela que pensa que seus próprios valores e identidades essenciais não têm relação com os tradicionalmente expressos pela religião. São esses dois últimos tipos de secularismo - a cultura pública secular e a pessoa secular - que são relativamente novos na história humana. Eles são um emblema do Ocidente europeu e norte-americano, desde o século XVIII até ao presente, começando com o Iluminismo que inaugurou uma nova forma de pensar a religião. Esta noção de religiāo oferecia uma definição restrita. Ao invés de vê-la como um repositório de símbolos culturais, identidade comunitária e como um conjunto de valores sociais, definia-a em termos de instituiçóes eclesiais e crenças dogmáticas. Era este tipo de religião que era considerado problemático e conceitualmente desconectado da restante vida social. O que muitas pessoas na Europa receavam na época era o poder econômico e político do clero católico romano e o fanatismo associado às terríveis guerras religiosas dos séculos XVI e XVII. Isso poderia ser controlado em uma sociedade na qual esses fatores, agora definidos como religião, tivessem suas limitaçôes dentro de uma sociedade não religiosa.

O termo secularismo surgiu depois e tem menos de 200 anos. Foi primeiramente usado por um escritor agnóstico britânico, George Jacob Holyoake, em 1851, para descrever o tipo de cultura pública que gostaria de ver substituir a religião (HOLYOAKE, 1896). Todavia, suas raízes iluministas são anteriores, quando o termo para Iluminismo - lumières em francês e Aufklärung em alemão - se tornou em uma representaçáo de valores seculares modernos e a razão começou sendo entendida como a antítese do que os pensadores iluministas desdenhavam sobre o dogmatismo religioso. Assim sendo, na Europa dos séculos XVII e XVIII, a razão secular era entendida como uma ideologia 
de ordem pública que substituiria a religião, enquanto força principal na organizaçáo da sociedade. O pensamento racional seria a única medida verdadeira de valor dos objetivos sociais, deixando a religiáo de informar os ideais e valores públicos. Na França, as igrejas abandonadas foram transformadas em templos de razão para celebrar essa transformação.

Essa marginalização da religião nunca foi perfeita no Ocidente. Sociedades religiosas, abraçando valores religiosos na vida pública, emergiram em comunidades tấo pequenas tais como a colônia New Harmony em Indiana, no século XIX, e a grande comunidade mórmon que se desenvolveu em Utah e se disseminou pelo Oeste dos EUA. Em outras regióes do mundo, a secularização que acompanhou a colonizaçáo europeia nunca foi totalmente integrada, nomeadamente em sociedades para as quais as tradiçóes religiosas eram parte essencial de suas identidades. Para a maioria do mundo, a cultura religiosa era a cultura da sociedade, e a arte, a literatura e a vida intelectual seriam impensáveis sem ela.

Antes do advento do Iluminismo europeu, a religião (no sentido de história, ideias e símbolos religiosos) era uma parte integrante da cultura de fundo das sociedades na Europa e na maioria das regióes do mundo. Em cada um desses locais existiria, normalmente, apenas uma cultura, uma moralidade e um conjunto de virtudes públicas; as concepçóes e tradiçóes religiosas faziam parte delas. Deste modo, as ideias - mesmo as mais inovadoras e transformadoras - seriam expressas em termos religiosos ou basear-se-iam na história, ética e teologia religiosa. Adam Smith, um economista do século XIX, foi educado tanto como teólogo como filósofo moral. O biólogo Charles Darwin também tinha formação em teologia. Tal como observou o historiador da religiāo Wilfred Cantwell Smith, o próprio termo religião raramente foi usado na era pré-Iluminismo, porque não havia nada com o qual contrastá-lo (SMITH, 1963). Antes do uso comum da palavra religiāo, para demarcar uma esfera separada de atividade e ideias, usavam-se, ao invés, os termos tradição, fé e crença. Não que a religião inexistisse, no nosso sentido da palavra: havia igrejas e rituais e doutrinas, entre outros. Contudo, eles estavam perfeitamente integrados na cultura; não existia o conceito de uma cosmovisão separada que precisasse de designação. Não havia, portanto, necessidade para a palavra religião. 
O pensamento iluminista ofereceu uma forma diferente de ver a situação. A vida pública das sociedades era, essencialmente, aquela intocada por crenças, tradiçốes, rituais e poder clerical, comumente associados às instituiçôes religiosas. Um conceito completamente novo foi criado - a nossa noção de religiāo - que era aquilo que se podia fazer em privado, em um dia de folga. Foi o lado contrário dessa nova forma de estar no mundo, a noçáo iluminista da sociedade racional, que nos serve de base para pensar o secularismo. Ela serviu para demarcar duas formas de ser. Quando um indivíduo estivesse na vida pública, discutindo, criando e votando regras para a sociedade, ele era secular. Quando estivesse em casa ou na igreja, o indivíduo podia voltar-se para a religião - ou optar por não fazê-lo. Era algo privado e pessoal. Tal como William James (1982, p. 31), um racionalista e psicólogo da religião do século XIX, afirmou, a religião era algo que os humanos faziam em "sua solidáo".

Nas sociedades pós-iluministas, com efeito, a missão de prover moralidade social e coesão comunitária foi transferida da cultura religiosa para a sociedade secular. Tem sido uma responsabilidade pesada de suportar. No século XIX, um grupo de intelectuais franceses denominado ideologues, as pessoas dedicadas a ideias, criou um conceito ou ideologia que apontava para um sistema de valores e ideias seculares que deveriam substituir a moralidade social da religião. De acordo com um dos ideologues, Destutt de Tracy, cujo livro Elements of Ideology introduziu o termo no mundo, a lógica deveria ser a única base das ciências politicas e morais (COX, 1969, p. 17).

Esse sentimento de coesão social que a religiáo havia oferecido foi, eventualmente, substituído pelo nacionalismo secular, uma ideia surgida no século XVIII e disseminada pelo mundo nos séculos XIX e XX. Alexis de Tocqueville (1955 [1856], p. 11), um analista social francês, considerava que o fervor na-

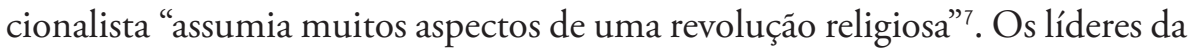
revoluçáo americana pensavam, igualmente, que sua nova sociedade secular substituiria aquela baseada na religião. Muitos dos fundadores estadunidenses tinham sido influenciados pelo deísmo do século XVIII, uma religião da ciência e da lei natural que se "dedicava a expor a religião [da igreja] à luz do

Conforme, também, John McManners: The French Revolution and the Church (Westport, CT: Greenwood Press, 1969). 
conhecimento" (CASSIRER, 1955, p. 171) ${ }^{8}$. O nacionalismo estadunidense substituiu, tal como na França, a cultura religiosa por um nacionalismo secular que tinha suas próprias características religiosas, combinando os ideais do nacionalismo e os símbolos do cristianismo no que foi chamado de "religião civil" (BELLAH, 1967). Com efeito, as formas extremas de nacionalismo ganharam uma aura sagrada que ordenava a lealdade exclusiva e desafiava quaisquer outras formas de associação voluntária, incluindo as religiosas. Em meados do século XX, as ideologias nacionalistas, ligadas ao fascismo italiano, ao nacional-socialismo alemão e à visão limitada de Stalin sobre o socialismo estatal na União Social Comunista, eram inimigas tanto da religião como do nacionalismo moderado da maioria dos Estados-nação.

$\mathrm{Na}$ maior parte das outras regióes do mundo, onde a ideia do Estado-nação secular se apossou, foi desenvolvida uma relação bastante confortável entre política secular e religiáo organizada. Os líderes seculares não precisariam se preocupar com a conformidade aos ensinamentos e valores religiosos, visto que estavam separados deles; e os líderes religiosos não tinham que assumir responsabilidade pela manutenção da ordem social, nem pela direção moral da vida pública, uma vez que isso se transformou em uma prerrogativa dos políticos seculares. Ambos os lados parecem ter aprendido a conviver com a dicotomia entre religião e secularismo e a beneficiar-se dela.

Mesmo no mundo não Ocidental, herdeiro indireto do pensamento dicotômico secular-religioso do Iluminismo, uma forma de secularismo se enraizou. Na Índia ela não significava uma separação da religião da vida pública, mas a sua igualdade de acesso por todos os grupos religiosos; o Estado indiano oferecia uma estrutura de governo neutra sobre uma sociedade profundamente dividida em várias comunidades religiosas. Portanto, na Índia, todos os grupos religiosos - muçulmanos, hindus, sikhs e cristãos - poderiam estar seguros de que seu governo central náo favoreceria qualquer comunidade religiosa em detrimento de outra. No entanto, em países como a Turquia, o Egito e o Irã pré-revolução os líderes políticos adotaram uma filosofia de secularismo diferente: a religiáo era mantida fora da vida pública. Nesses Estados, o governo não só devia manter uma distância entre os campos religiosos em

8 Entre os devotos do deismo encontravam-se Thomas Jefferson, Benjamin Franklin e outros fundadores dos EUA. 
disputa como também devia substituir sua influência na sociedade. Líderes como Ataturk na Turquia e Nassar no Egito consideravam que a cosmovisão secular era a perspectiva moderna do mundo, a vaga do futuro, e estavam ávidos para pôr suas sociedades no caminho do devir secular, em vez do passado religioso. A secularidade não queria dizer, como no caso indiano, apoio igual a todas as religióes. Pelo contrário, significava a condição subordinada de todas as religiōes ao programa de modernização.

Os séculos XIX e XX viram a realização da profecia de Tocqueville (1955 [1856], p. 13) que antecipava que a "estranha religiáo" do nacionalismo secular iria, "como o Islá, conquistar todo o mundo com seus apóstolos, militantes e mártires". De fato, disseminou-se pelo globo com um zelo quase missionário, tendo sido enviado para áreas recém-colonizadas na Ásia, África e América Latina, como parte do pacote ideológico do colonialismo. Tornou-se o parceiro ideológico do que ficou conhecido como construção da nação. Ao nível social, isso correspondia à crença de que o nacionalismo secular podia triunfar sobre as identidades religiosas paroquiais, frequentemente vistas como inimigas do nacionalismo emergente. $\mathrm{Na}$ Índia, por exemplo, a identidade política baseada na afiliaçáo religiosa foi chamada de comunalismo - algo que se precisava banir da nova naçáo. No entendimento de Nehru e de outros líderes seculares, a religião era a principal adversária de um objeto de lealdade ainda maior: a Índia secular. Nehru rogou aos seus concidadáos que se livrassem daquilo que designou de perspectiva redutora da religiáo e que adotassem um ponto de vista moderno e nacionalista.

\section{0 desafio ao secularismo $e$ a ascensão da religião radical}

No século XXI, a religiâo voltou para a vida pública com sede de vingança. Em alguns casos, tem um papel positivo no apoio a vozes de tolerância em sociedades multiculturais. Mas, em muitos outros casos, as vozes religiosas são ásperas e irascíveis, conduzindo, por vezes, à violência ${ }^{9}$. Em ambos os casos, o papel público da religião desafiou os observadores do século XIX e XX que anteciparam que a religião desapareceria, como disse Karl Marx, ou recuaria para a esfera privada da solidão dos indivíduos, como William James imaginou.

9 Para uma perspectiva geral do crescimento da religião pública no século XX, ver: Juergensmeyer, Griego $e$ Soboslai, 2015. 
$\mathrm{O}$ que aconteceu? $\mathrm{O}$ que têm as sociedades à volta do mundo que tenha produzido um fenômeno quase global de ascensão do ativismo religioso e um sentimento estridente de antissecularismo? É pouco provável que seja pura coincidência que novos ativistas religiosos tenham surgido ao mesmo tempo - nas últimas décadas do século XX e nas primeiras do XXI - em locais táo distintos como no Mianmar, Sri Lanka e Japão budista, no Oriente Médio judeu e muçulmano, na Ásia Meridional hindu e sikh, na África muçulmana e cristã e nas naçóes cristãs da Europa e das Américas. Alguma coisa estava acontecendo, algo de uma natureza quase global que afetou a maioria das culturas e áreas do planeta.

A palavra global é uma pista para o que isso possa ser. Quando o muro de Berlim caiu em 1989, assinalando o fim da Guerra Fria, já uma nova era havia começado, a era da globalizaçáo. $\mathrm{Na}$ época, alguns analistas pensaram que isso significava que o Ocidente vencera a contenda e que os conflitos ideológicos, como o confronto entre socialismo e capitalismo, eram coisa do passado. Segundo Francis Fukuyama (1992), nos inícios da década de 1990, o mundo estava testemunhando o "fim da história". Todavia, o que realmente estava acontecendo era o término de um tipo de confrontação ideológica global e o começo de outra, ligada ao secularismo e à religião. Esse novo confronto ideológico foi, em várias das seguintes formas, uma resposta à globalização.

\section{A perda de fé no nacionalismo secular}

Em meados do século XX, a ideia do Estado-nação era indiscutível. Nessa época, a maioria dos países europeus tinha largado seu controle colonial e grandes impérios, como o Otomano, foram redesenhados (muitas vezes de forma incuriosa) por meio de novas fronteiras nacionais. A formação das $\mathrm{Na}$ ções Unidas, em 1945, como um órgão representativo, expressava um sentimento amplamente partilhado de que o mundo era inteiramente composto por Estados-nação autogovernados. Esses Estados eram quase exclusivamente seculares - ou seja, sua legitimidade era conferida apenas pelo que Jean Jacques Rousseau, um filósofo iluminista francês, chamara de contrato social entre os cidadãos de uma determinada região.

Contudo, nos finais do século, a ascensão da globalização havia erodido grande parte da autoridade do Estado-nação, enfraquecendo identidades 
nacionais e formas de controle regional. A produção, distribuição e o financiamento econômico transnacional eram administrados fora do âmbito das autoridades nacionais. As economias locais eram parte integrante de entidades econômicas globais, ávidas por explorar mão de obra barata em algumas regióes e encontrar novos mercados em outras. As moedas foram substituídas por transaçóes financeiras digitais e os exércitos nacionais eram essencialmente patrulhas de fronteira, incapazes de desafiar o poderio militar dos EUA que continuou sendo a única superpotência do planeta. Simultaneamente, os meios de comunicação e transporte global colocaram todo o mundo em contato. As novas formas de mídia social digital e a transmissão global da mídia significavam que todos os modos de cultura popular faziam, cada vez mais, parte de uma cultural global homogênea.

Talvez tão significativa tenha sido a desilusão que, em face do crescimento global de ditaduras autocráticas e de máquinas políticas corruptas e gananciosas, se abateu sobre as altas expectativas do nacionalismo secular democrático. Jürgen Habermas (1975) descreveu essa rejeição das premissas otimistas da política secular na contemporaneidade como: a "crise da legitimaçáo". As entidades seculares do Estado-naçáo nem sempre foram capazes de corresponder às próprias expectativas materialistas de riqueza e progresso. Ainda mais preocupante era o fato de parecerem incapazes de terminar com a ganância e corrupção das tentativas individuais de beneficiar com o sistema. Pareciam desprovidas de um compasso moral, algo que a religiáo oferecera no passado.

Em suma, na era da globalização, o mundo experimentou uma "perda de fé” no nacionalismo secular (JUERGENSMEYER, 2008, p. 10-17). É uma perda de $f e ́$, porque o nacionalismo, inclusive o secular, é uma comunidade imaginada que, para funcionar, necessita de uma crença na sua legitimidade e de um compromisso com suas possibilidades (ANDERSON, 1986). Quando essa fé se evapora, uma cidadania enfurecida pode emergir, atacando os pressupostos seculares que a sustentaram inicialmente e associando a falência do Estado secular ao próprio secularismo. Por isso, é compreensível que muitos indivíduos se voltem para outras formas de identidade e comunidade que pareçam temporalmente mais constantes e moralmente seguras. Com frequência, inclinam-se para a religião. 


\section{0 ataque secular à religião}

Em muitas partes do mundo os próprios termos secular e secularismo têm uma conotação sinistra. Tal como observámos anteriormente nesta dissertação, a dicotomia entre religião e secularismo é uma invenção bastante recente, um legado do Iluminismo europeu do século XVIII. Como duas formas de pensar sobre a realidade social, os vocábulos secularismo e religiāo foram forjados a partir de termos usados para designar ofícios clericais na Idade Média: o clero secular (de secularis, mundano), os que trabalhavam no mundo como párocos, e o clero religioso (de religare, vincular), aqueles que faziam votos de disciplina que os confinavam a mosteiros. Isso fazia sentido em inglês e em outras línguas europeias. Mas, em outras partes do mundo, encontrar termos para secular - e também para religião - revelou-se difícil. Por experiência própria, fazendo trabalho de campo na Índia, tive dificuldades para encontrar um termo que fosse equivalente ao inglês religion, acabando, frequentemente, com o vocábulo usado pelos missionários cristãos, dharma, melhor traduzido como lei natural ou ordem moral. Não existia uma palavra simples para religiáo.

O termo secular era mais difícil de traduzir. Nas línguas sânscritas do Norte da Índia, por vezes, foi usada a palavra adharma, mas o que isso realmente significa é a ausência de lei ou ordem moral, algo semelhante à anarquia. Outros termos também se referem à inexistência de religião, no sentido de ordem moral. No árabe, secularismo é traduzido às vezes como ilmaniya, pensamento científico, e por vezes como almaniya, mundanismo. No entanto, visto que o último também pode querer dizer materialismo crasso, ele possui uma conotação negativa em árabe, assim como em hindi. Além disso, nas culturas do Sul da Ásia e do Oriente Médio as ideias e imagens religiosas estão tão firmemente integradas na cultura pública que é impensável haver algum tipo de expressão cultural sem elas. Por isso, é provável que, na Índia, a noção de secularismo signifique igualdade e apoio público a todas as religiōes, em vez de uma oposiçáo à cultura religiosa e uma tentativa de substitui-la, como sucede na França ou na Turquia de Ataturk.

Uma vez que as versôes traduzidas da palavra secularismo têm conotações negativas no Sul da Ásia e no Oriente Médio, nessas regiôes, o estabelecimento de novos nacionalismos, com base na noção secular de Estado-nação, foi considerado problemático. Não surpreende que, quando as coisas se 
complicaram e as autoridades seculares começaram a ser vistas como corruptas ou ineficazes, as críticas se centrassem na base secular desses governos. Também é compreensível que tenha havido um aumento de novas políticas religiosas que oferecessem, ao poder político, uma legitimação religiosa, ao invés de uma secular.

A maioria das tradições religiosas fornece os recursos históricos para se pensar a religião em termos políticos. O reino davídico no Israel antigo, o poder papal na história cristã e os califas que governaram os impérios muçulmanos testemunham a interação próxima entre os poderes religioso e mundano nas histórias do Ocidente. Isso também é verdade nas tradiçôes orientais, incluindo o hinduísmo, onde a rajdharma era a autoridade moral que legitimava os governantes, e o sikhismo, onde muitos dos líderes da linhagem original de gurus tiveram de desembainhar armas para defender a crescente comunidade sihk dos séculos XVI e XVII.

Talvez de forma surpreendente a política também está associada ao budismo; isso é admirável, porque é uma tradição associada à não violência e a um suposto desinteresse pelo poder terreno. Mas, em particular, nas sociedades budistas theravada - em países como Tailândia, Sri Lanka e Mianmar (Birmânia) - o budismo tem sido associado, de forma estreita, ao poder político e às insurreiçóes contra autoridades seculares. Na Tailândia, a tradição especifica que o rei tem de ser um monge antes de assumir o poder político - deve ser um renunciador do mundo, antes de se poder tornar um conquistador do mundo (TAMBIAH, 1976). Em anos recentes, monges budistas no Sul da Tailândia trabalharam com os militares tailandeses no confronto com os muçulmanos rebeldes. Alguns monges até esconderam armas debaixo de suas vestes (JERRYSON, 2011). Tanto em Mianmar como no Sri Lanka houve movimentos políticos ruidosos a ser liderados por monges budistas revoltados, um dos quais assassinou um premiê no Sri Lanka. Nessas sociedades theravada existe um histórico de política budista que, há décadas, tem sido relacionado a movimentos nacionalistas. Logo após a independência da Birmânia, seus líderes estabeleceram um socialismo budista, guiado por uma mistura sincrética curiosa de ideias marxistas e budistas, pelo que não deve surpreender que muitos dos protestos no país contra o governo militar e as atuais tentativas de descredibilizar a legitimidade dos muçulmanos birmaneses tenham sido 
liderados por monges budistas. Deste modo, na Birmânia, assim como em muitas sociedades religiosas tradicionais, a "religiáo", tal como o cientista político Donald Smith (1971, p. 11) assevera, "responde à questão da legitimidade política".

O desafio religioso ao nacionalismo secular também cresceu na Europa e nos EUA (BALMER, 1989; CAPPS, 1990; LAWRENCE, 1989). Não obstante as naçôes europeias tenham sido fundadas em princípios do Iluminismo que excluíam a religiáo, no clima anti-imigração da Europa moderna, muitos nacionalistas advogam que seus países são cristáos, sendo, portanto, inerentemente hostis a estrangeiros não cristãos. Nos EUA, uma nação de imigrantes, surgiu um xenofobismo semelhante. E embora os fundadores dos EUA fossem, quase todos, secularistas e deístas (uma crença não sectária na lei natural do mundo), alguns conservadores insistem que, de fato, o país se fundou no cristianismo e na Bíblia. Quando entrevistei um militante cristão em Maryland, condenado pelo bombardeio de clínicas que ofereciam serviços de aborto, ele disse que sonhava com uma América que não confiasse na Constituição secular, mas na Bíblia. Nos EUA contemporâneos, bem como em outros países em torno do mundo, o secularismo é visto como o competidor da religião.

\section{A percepção de que o secularismo reforça o poder global ocidental}

O secularismo é visto também como algo que não é universal, mas como uma ideologia caracteristicamente europeia e estadunidense. Por isso, também é considerada um agente da dominação ocidental, em todos seus campos - culturais, econômicos, políticos e militares.

O aspecto cultural é encarado como particularmente insidioso, porque parece amiúde muito atrativo, em especial para os jovens. Em muitas partes do Oriente Médio, nos últimos anos, o programa televisivo mais popular não tem sido da rede de notícias $\mathrm{Al}$ Jazira, nem de qualquer dos televangelistas muçulmanos que foram surgindo na regiáo. Pelo contrário, o mais visto foi uma repetição dublada em árabe da antiga sitcom estadunidense Friends. O programa de televisão é inócuo aos olhos da maioria dos norte-americanos e europeus. Todavia, a sua exibição de sexualidade fácil e de interações 
descomprometidas entre os gêneros é ofensiva para muitos líderes religiosos tradicionais no Oriente Médio. Na melhor das hipóteses, veem-nas como algo pecaminoso e, na pior, como conspiratório, uma ferramenta sinistra das potências ocidentais para manipular a juventude mundial e agregá-la ao sistema de valores de sua sociedade global comum. Talvez uma das maiores conquistas da globalização - se é que essa é a palavra correta para usar - é a criação de uma cultura popular global. Contudo, muitas de suas imagens não são assim tão globais. Elas são distintivamente estadunidenses, relacionando-se, mais especificamente, com a liberdade moral de uma Califórnia do Sul moderna e soalheira. Essa atitude descomprometida, relativamente à moralidade tradicional, é considerada alarmante em sociedades mais tradicionais da Ásia, África e Oriente Médio. A cultura juvenil comum que sugere é vista como tendo uma motivaçáo política subjacente, outro aspecto do controle global do Ocidente. Quando, em 1996, Osama bin Laden lançou uma fatwa de guerra contra os EUA, apontou várias críticas ao Ocidente, incluindo sua opressão econômica, pela exploração dos recursos petrolíferos do Oriente Médio; sua opressão política, ao apoiar ditadores na região; sua opressão militar, com o estabelecimento de bases militares estadunidenses na Arábia Saudita e em outros locais; e sua dominação cultural - igualmente opressora - através de imagens da mídia. Desde então, o poder da mídia mundial somente aumentou com o advento de redes sociais como o Twitter e o Facebook, permitindo uma comunicação mais fácil entre as pessoas e, também, a transmissão global de valores culturais homogêneos.

Por norma, considera-se que os valores inerentes à cultura secular global pretendem erodir aqueles das culturas religiosas tradicionais. Em um projeto sobre religião na sociedade civil global, que dirigi recentemente, descobriu-se que muitos líderes religiosos tradicionais, da África à Rússia, estavam convencidos de que o apoio secular aos direitos homossexuais era um mecanismo destinado a enfraquecer a cultura tradicional. $\mathrm{O}$ argumento dos direitos humanos era descartado, porque, em sua perspectiva, não poderia ser estendido a pessoas que estavam envolvidas em claros atos de imoralidade. As nossas tentativas de fundamentar o argumento moral criaram alguns dos encontros mais tensos no projeto global, como relatamos no livro God in the Tumult of the Global Square. 
O secularismo também é visto como um modo de promoção dos interesses econômicos estadunidenses. Quando entrevistei mullahs sunitas no Iraque em 2004, após a invasão e ocupação de seu país pelos EUA, fiquei surpreso com o número dos que estavam convencidos de que a política da regiáo estava sendo manipulada para garantir ganhos econômicos aos EUA. Alguns pensavam que o petróleo estava por trás de tudo. Outros consideravam que os EUA estavam tentando criar uma ordem mundial que se pudesse controlar facilmente, por meio do benefício de grandes corporaçóes.

Outros viam os EUA apoiando a política secular tendo em vista uma agenda política maior - a dominação global de sistemas políticos pelo mundo. Um dos mullahs, um líder da Associação de Clérigos Muçulmanos na regiấo de al Anbar, nas províncias iraquianas ocidentais, dominadas por sunitas, disse-me que estavam convencidos de que as tropas estadunidenses invadiram e ocuparam o Iraque somente para impedir que a revoluçáo islâmica se expandisse no país. Esses mullahs consideravam que os EUA estavam tentando impor um governo secular, porquanto esse era o inimigo do islá. $\mathrm{O}$ que me impressionou nessa comparação foi que eles estavam equiparando os dois, julgando que um Estado secular estava em competição com o que consideramos ser apenas uma religião. Os mullahs não gostavam do socialismo do partido Baath de Saddam Hussein, uma vez que era secular, e consideravam que a ocupação norte-americana estava procurando substituir a norma secular inepta de Saddam por uma ordem secular americana mais forte, pois a consideravam vulnerável a uma revolta islâmica. Curiosamente, alguns desses líderes muçulmanos sunitas hoje apoiam o ISIS em seus territórios do Oeste iraquiano, de modo que agora têm a revolução islâmica que queriam, mas talvez não da forma desejada.

Esses ativistas religiosos veem o secularismo como parte de uma competição global entre o Ocidente e as sociedades religiosas tradicionais. É uma perspectiva da política mundial que náo difere daquela apresentada pelo cientista político de Harvard, Samuel Huntington (1995). O autor considerou que as civilizaçôes europeia e estadunidense estavam sendo sitiadas, uma noção adotada, no pós-09/11, pelos decisores políticos neoconservadores do governo do presidente George W. Bush, muitos dos quais, por seu turno, haviam sido influenciados pelas ideias do filósofo da Universidade de Chicago Leo Strauss. 
Neste quadro de referência, o secularismo fazia parte da civilização ocidental, por isso era compreensível que fosse desafiado e rejeitado pelas culturas religiosas de civilizaçóes hostis, incluindo primeiramente o islá. Apesar de esta tese ter sido amplamente rejeitada pela maioria dos membros da comunidade académica, tornou-se em um tema importante durante a administração Bush, sendo largamente aceito nos círculos políticos conservadores do Ocidente, muitos anos depois, e contribuindo para a islamofobia das sociedades da Europa e dos EUA.

Uma razão pela qual as convicçóes religiosas são organizadas em resposta ao secularismo e às instituiçôes seculares está na percepção de que o secularismo não é neutral, porque tem um carácter religioso. Isso está implícito na tese do choque de civilizaçôes de Huntington que combina cristianismo ocidental e secularismo e explica por que muitos dos críticos náo ocidentais consideram, amiúde, o último como um projeto religioso. Benedict Anderson, observando a facilidade com que tais ideologias seculares conseguem justificar genocídios - desde o nacional-socialismo de Hitler ao socialismo cambojano de Pol Pot -, encontra uma forte afinidade entre o imaginário nacionalista e o imaginário religioso. A ascensão do nacionalismo secular na história mundial tem sido, segundo Anderson (1986, p. 18), uma extensão “[...] dos grandes sistemas culturais que o precederam, a partir dos quais - mas também contra os quais - ele emergiu". O nacionalismo secular suscita muitas vezes uma resposta quase religiosa, surgindo frequentemente como um tipo de "nacionalismo cultural”, tal como o descrito por Howard Wriggins (1960, p. 169) ao falar dos sentimentos nacionalistas cingaleses. Não só engloba os valores culturais partilhados pelas pessoas dentro das fronteiras nacionais existentes, ou potencialmente existentes, como também invoca uma resposta cultural própria.

Até nos EUA, o secularismo é regularmente considerado suspeito pelas comunidades religiosas conservadoras. Entre os extremistas religiosos estadunidenses, o secularismo não é visto como um agente do imperialismo ocidental, mas como o precursor de um novo tipo de imperialismo global, formado pelo que comumente se designa por nova ordem mundial. Esse novo poder transnacional é aquele que os políticos seculares norte-americanos, em especial os da esquerda, têm apoiado de forma voluntária. É também ele que promove o multiculturalismo, alegadamente, como um meio para enfraquecer a força e pureza das sociedades religiosas tradicionais. 
Nos últimos anos, essa teoria conspiratória sobre o papel do secularismo e do multiculturalismo na promoção da nova ordem mundial, tem feito parte do discurso de alguns dos atos mais selvagens do terrorismo cristão. $\mathrm{O}$ ataque à bomba ao edifício federal de Oklahoma City, por Timothy McVeigh, em 1995, e o ataque ao acampamento juvenil norueguês, por Anders Breivik, em 2011, tiveram motivaçóes extraordinariamente semelhantes: uma percepção de que suas nações cristâs estavam sendo atacadas por noçóes seculares de multiculturalismo. O título do manifesto de Breivik é 2083, uma data que, segundo ele, será o culminar de suas ações e o aniversário do ano 1683, quando, na batalha de Viena, o exército imperial otomano foi derrotado após longas confrontaçóes, garantindo assim que a maioria da Europa náo se tornasse parte do império muçulmano. Na mente de Breivik, estavam-se recriando os esforços históricos para salvar a Europa do que imaginava serem os males da civilização islâmica.

Timothy McVeigh não era escritor; ao invés copiava e citava seu livro favorito, o romance The Turner Diaries, escrito pelo neonazista William Pierce, sob o pseudônimo Andrew Macdonald. Essa obra explica as motivaçóes de McVeigh de um modo assustadoramente semelhante aos escritos de Breivik, no livro 2083: o primeiro, tal como o último, pensava que os políticos liberais se tinham entregado às forças do multiculturalismo secular e que as "pessoas da lama”, não brancos, não cristãos, não heterossexuais e homens não patriarcais estavam tentando assumir o controle do país. Para salvá-lo e para defender a cristandade, os homens cristãos brancos e justos, heterossexuais e não feministas tiveram de levar um choque de realidade, nomeadamente através da força de uma explosão que lhes assinalaria o início da guerra. Essas eram as ideias de McVeigh a partir do The Turner Diaries, mas também eram as de Breivik. Deste modo, curiosamente, a imagem da dominação global acirra tanto medo no Ocidente, entre alguns conservadores religiosos extremistas, como nas regiôes das antigas colônias ocidentais.

\section{A guerra imaginada}

A discussão dos terroristas cristãos, Timothy McVeigh e Anders Breivik, leva-nos à questão da violência no conflito imaginado entre secularismo e religião. Sáo casos nos quais a guerra imaginada se torna real, pelo menos no 
sentido da execução de açôes violentas destinadas a assaltar a consciência pública e a invocar imagens de conflito que, para os perpetradores, são emblemáticas de batalhas no mundo real. As similaridades entre os imaginários religioso e secular, descritas pelo antropólogo Benedict Anderson, sustentam a ideia defendida por muitos dos atuais ativistas religiosos: a religiáo pode oferecer uma justificação para o poder que, baseada na violência, é a base da política moderna. Se o secularismo, como uma noção imaginada de ordem social, é capaz de oferecer legitimidade ideológica às comunidades políticas modernas, essa mesma função legitimadora pode ser estendida ao seu conceito concomitante, a ideia de religião. Os ativistas religiosos de hoje são inconscientemente modernos, em particular, porque aceitam a mesma noção do Iluminismo de que existe uma diferença fundamental entre as esferas religiosa e secular. Esses ativistas pensam que estão simplesmente reclamando o poder político do Estado, em nome da religiáo. Esse poderia ser um arranjo viável em um mundo pré-moderno, onde as sensibilidades religiosas se interligavam a um sentido amplo de ordem moral e onde uma política religiosa podia abraçar uma sociedade pluralista e variada. No século XXI, infelizmente, essa ideia de religião está cada vez mais desatualizada.

A ironia é que a noção moderna de religião, gradualmente aceita pelo mundo, é muito mais estreita do que isso; é uma ideia que diz, em consonância com a concepção do Iluminismo, que a religião é apenas um conjunto particular de doutrinas, limitado a comunidades confessionais específicas. É essa noção redutora e fundamentalista da religião que agora se afirma com poder político, do ISIS à direita cristã militante. O Frankenstein da religião - criado pela imaginaçáo iluminista - ergueu-se para reivindicar o feito mais brioso do Iluminismo, o Estado-nação. A tragédia está no fato de o desafio à ordem secular, derivado desse tipo de nacionalismo religioso, sacudir as fundaçôes do poder político visto que são frequentemente estridentes e violentas.

\section{Referências}

ANDERSON, B. Imagined Communities: Reflections on the Origin and Spread of Nationalism. New York: Verso Books, 1986.

ASAD, T. Formations of the Secular: Christianity, Islam, Modernity. Stanford, CA: Stanford University Press, 2003. 
BALMER, R. Mine Eyes Have Seen the Glory: A Journey into the Evangelical Subculture in America. New York: Oxford University Press, 1989.

BELLAH, R. Civil Religion in America. Daedalus, v. 96, n. 1, p. 1-22, inv. 1967.

CALHOUN, C.; JUERGENSMEYER, M.; VAN ANTWERPEN, J. (Ed.). Rethinking Secularism. Oxford: Oxford University Press, 2011.

CAPPS, W. H. The New Religious Right: Piety, Patriotism, and Politics. Columbia: University of South Carolina Press, 1990.

CASSIRER, E. The Philosophy of the Enlightenment. Boston: Beacon Press, 1955.

COX, R. H. Ideology, Politics, and Political Theory. Belmont: Wadsworth, 1969.

FUKUYAMA, F. The End of History and the Last Man. New York: Free Press, 1992.

HABERMAS, J. Legitimation Crisis. Traducing Thomas McCarthy. Boston: Beacon Press, 1975.

HOLYOAKE, G. The Origin and Nature of Secularism. Londres: Watts and Co., 1896.

HUNTINGTON, S. The Clash of Civilizations and the Remaking of World Order. New York: Simon and Schuster, 1995.

JAMES, W. The Varieties of Religious Experience. New York: Penguin Books, 1982.

JERRYSON, M. Buddhist Fury: Religion and Violence in Southern Thailand. New York: Oxford University Press, 2011.

JUERGENSMEYER, M. Global Rebellion: Religious Challenges to the Secular State. Berkeley: University of California Press, 2008.

.; GRIEGO, D., SOBOSLAI, J. God in the Tumult of the Global Square: Religion in Global Civil Society. Berkeley: University of California Press, 2015.

LAWRENCE, B. B. Defenders of God: The Fundamentalist Revolt against the Modern Age. New York: Harper \& Row, 1989.

SMITH, C. W. The Meaning and End of Religion. New York: Macmillan, 1963.

SMITH, D. E. (Ed.). Religion, Politics, and Social Change in the Third World: A Sourcebook. Nova Iorque: Free Press, 1971.

TAMBIAH, S. J. World Conqueror and World Renouncer: A Study of Buddhism and Polity in Thailand against a Historical Background. Cambridge: Cambridge University Press, 1976. 
TAYLOR, C. A Secular Age. Cambridge: Belknap Press at Harvard University, 2007.

TOCQUEVIlLE, A. [1856]. The Old Regime and the French Revolution. Traducing Stuart Gilbert. New York: Doubleday, Anchor Books, 1955.

WRIGGINS, W. H. Ceylon: Dilemmas of a New Nation. Princeton: Princeton University Press, 1960.

\section{The Imagined War Between Secularism and Religion}

\section{Abstract}

The case of the 2015 attack on the offices of the Charlie Hebdo satirical magazine in Paris illustrates the imagined war between secularism and religion that is in the background of many incidents of violence at the turn of the $21^{\text {st }}$ century. The Enlightenment idea that there are two different worldviews - two distinctly different spheres of understanding about reality-one of them secular and the other religious, is inherently problematic. This dichotomy creates an arena of discord that is easily exploited by people who feel isolated and marginalized for whatever reason and look for someone to blame and some battle to join. It is a false conflict which extremists on both sides, religious and secular, have exacerbated.

Keywords: Terrorism. Religious violence. Secularism. Cosmic war.

Recebido em: 22/11/2016. Aprovado em: 23/01/2017. 